\title{
Molecular Markers of Kidney Cancer Progression, Association with Efficiency of Pazopanib Therapy
}

\author{
Liudmila V. Spirina1, Evgeny A. Usynin², Irina V. Kondakova², Zahar A. Yurmazov², \\ Elena M. Slonimskaya ${ }^{1}$ \\ ${ }^{1}$ Tomsk Cancer Research Institute, Siberian State Medical University, Tomsk, Russia \\ ${ }^{2}$ Tomsk Cancer Research Institute, Tomsk, Russia \\ Email: spirinalv@oncology.tomsk.ru
}

Received 26 June 2015; accepted 8 November 2015; published 11 November 2015

Copyright $@ 2015$ by authors and Scientific Research Publishing Inc.

This work is licensed under the Creative Commons Attribution International License (CC BY).

http://creativecommons.org/licenses/by/4.0/

(c) (i) Open Access

\begin{abstract}
Purpose: The aim of the study is to reveal associations between NF- $\kappa \mathrm{B}$, HIF-1alpha, VEGF expressions, proteasome and calpain activities with tumor progression in patients with kidney cancers and to find molecular parameters, associated with the effective pazopanib therapy. 93 patients with clear cell kidney cancers are included in investigation. 26 patients with disseminated kidney cancer have the pazopanib therapy. Methods: Transcription factors, VEGF, VEGFR2 and p-m-TOR expression are measured by ELISA kits. Proteasome and calpain activity are determined using specific fluorogenic substrate. Results: It is found the increase of NF- $\kappa \mathrm{B}, \mathrm{HIF}-1$ expression in cancer tissues followed the hematogenic metastasis development. Coefficient NF- $\mathrm{B}$ p65/p50 and VEGF expression are increased in cancer tissues with single metastasis and are decreased in cancer tissues with multiple ones. It is observed in the low proteasome activity in metastatic cancer tissues. The partial cancer regression is revealed in $29.6 \%$ of patients treated with pazopanib, cancer stabilization-in $61.5 \%$ of patients and cancer progression-in $11.5 \%$ of patients. The increased level of transcription factors NF- $\kappa$ B, HIF-1, growth factor VEGF and high proteasome activity in cancer tissues before targeted therapy are associated with the effective treatment. It is obtained the significant decrease of investigated markers after pazopanib application in metastatic kidney cancer patients. Conclusion: Coefficient NF- $\kappa$ B p65/p50, VEGF expression and proteases activities are the potential prognostic molecular markers of hematogenic metastasis development in kidney cancers. NF- $\kappa$ B, HIF-1 and VEGF levels can be considered as additional molecular markers predicting the effective pazopanib therapy.
\end{abstract}

\section{Keywords}

Kidney Cancer, NF-אB, HIF-1, VEGF, VEGFR2, m-TOR, Proteasome, Calpain, Pazopanib 


\section{Introduction}

The kidney cancer prevalence grows at present worldwide and remains the most aggressive disease among other cancers through its high mortality and poor overall survival. Survival is very much related to the stage of cancer when it is diagnosed. Almost 90 percent of kidney cancer patients are still alive after five years if the cancer is discovered before it spreads [1]. This fact is associated with the increase of primary incidence and also with involvement of imaging tests such as an ultrasound or a CT scan that can improve the diagnosis [2]. Many kidney cancers are found fairly early, while they are still confined to the kidney, others are found at a more advanced stage. The most common of these reasons is the character of growth without causing any pain or other problems till the cancer becomes quite large. On the other hand, there are no recommended screening tests for kidney cancer in people who are at increased risk [3].

There has been an increased understanding of the tumor biology of renal cell carcinoma (RCC). The identification of vascular endothelial growth factor (VEGF), its related receptor and the mammalian target of rapamycin (m-TOR) as dysregulated signaling pathways in the development and progression of RCC has resulted in the rational development of pharmaceutical agents which are capable of specifically targeting key steps in these pathways. However, metastatic RCC will progress in all patients, resulting in a critical need to determine patient risk and optimize treatment. It is shown the proteolytic regulation of NF- $\kappa \mathrm{B}$, HIF-1alpha and VEGF expressions in all cells. So the understanding of the biological mechanisms of kidney cancer progression will open the new prognostic factors and predictive biomarkers to facilitate individualized treatment selection and predict patient response to therapy [3]-[5].

Transcription factor HIF-1 is a heterodimer of alpha and beta subunits. Beta subunit is constitutionally expressed, whereas the activity of HIF-1 depends on alpha-subunit expression and its posttranslational modifications. Hydroxylation of proline and asparagine residues in HIF-1 $\alpha$ results in its binding to the von Hippel-Lindau protein (pVHL), is followed by HIF-1 alpha polyubiquitination and degradation in the proteasome [6] [7]. Under hypoxic conditions HIF-1 alpha subunits heterodimerize with beta subunits. The result of HIF activation is a production of vascular endothelial growth factor (VEGF) that stimulates vasculogenesis and angiogenesis. It is known as neoplastic neoangiogenesis via the VEGF tyrosine kinase and m-TOR pathways is resultant in cancer cell growth and progression.

The key transcription factor is NF- $\kappa \mathrm{B}$ that controls the transcription of DNA. NF- $\kappa \mathrm{B}$ is found in almost all animal cell types and is involved in cellular responses to stimuli such as stress, cytokines, free radicals, ultraviolet irradiation, apoptosis and immune reaction [8]. A subfamily of NF- $\kappa \mathrm{B}$ proteins includes five genes endcoding five main proteins: NF- $\kappa \mathrm{B} 1$, NF- $\kappa \mathrm{B} 2$, RelA (p65), RelB, c-Rel. The NF- $\kappa \mathrm{B} 1$ and NF- $\kappa \mathrm{B} 2$ proteins are synthesized as large precursors, p105, and p100, which undergo processing to generate the mature NF- $\kappa \mathrm{B}$ subunits, p50 and p52, respectively. The processing of p105 and p100 is mediated by the ubiquitin/proteasome pathway [9]. The proteins form the homo- and heterodimers of different structure. The active form of transcription factor $\mathrm{NF}-\kappa \mathrm{B}$ is the heterodimer p65/p50 [10]-[13]. The ratio of functional NF- $\kappa \mathrm{B}$ subunit dimers comprised of p50/p50 homodimers relative to p65/p50 heterodimers can act as a molecular switch in cell processes [12]. The transcription factors mutually influence each other, and this fact implies the existence of a complex regulation of their expression and activity and a cross-talk between these factors. So far, HIF- $1 \alpha$ level has been shown to change in NF- $\kappa$ B-dependent manner [12] [14].

The proteolysis is one of the mechanisms for regulation of transcription factors NF- $\kappa$ B and HIF- 1 alpha, and the proteasome and calpain systems are the most possible factors to be involved. The proteasome is the multicatalytic complex that consists of the catalytic core (20S) with one or two regulatory particles attached to it. In case when at least one of these particles is PA700 (19S regulatory particle), it is the 26S proteasome that performs mostly ATP- and ubiquitin-dependent proteolysis of multiple cellular proteins [15] [16]. It is necessary to note it is observed the role of proteasome in oncogenesis of breast [17], colon [18] and so on. But in case of kidney cancer the investigations were performed in cell culture. The use of proteasome inhibitors in kidney cancer cell line leads to the development of cytostatic effect [19]-[21], which mechanism is still unknown. Besides, Wu W.K., et al. have found that inhibition of protein degradation by proteasome inhibitor represses m-TOR signaling in RCC culture [22].

The question about proteolytic regulation of growth and transcription factors expression is still open. Decrease in HIF-1 $\alpha$ degradation in presence of proteasome inhibitors or under hypoxia, leads to a significant increase in both VEGF and its m-RNA expression in tumor cells [23] [24]. Moreover, calpains where shown to be 
involved in HIF- $1 \alpha$ destruction [Zhou J., 2006]. Activation of the NF- $\kappa$ B is effected by proteasomes. NF- $\kappa$ B is presented in cytoplasm in complex with its own repressor I $\kappa \mathrm{B}$. The key moment of NF- $\kappa \mathrm{B}$ activation belong to breaking the ties between the transcription factor and repressor. The $i-\kappa \mathrm{B}$ inhibitor molecules are modified by a process called ubiquitination, which then leads them to be degraded by proteasomes [9] [10]. Currently even greater significance is attached to the investigation on the participation of calpains in I $\kappa \mathrm{B}$ destruction [25]. The additional mechanism in NF- $\kappa$ B regulation serves the NF- $\kappa$ B protein forming from precursors which is mediated by proteasomes through the modification of p105 [26].

At present, it is known the cancer cells growth and proliferation is associated with the HIF-1alpha and VEGF expression [27]. Also the prevailing literature has focused on the most common type, the clear cell RCC subgroup. RCC is dominated by inactivating mutations in VHL, leading to constitutive activation of the hypoxia-inducible factors (HIFs) and resultant hypoxia response transcription signature, including changes that markedly affect cellular metabolic programs. The group of investigators has shown the increase of HIF-1alpha and VEGF expressions followed to tumor growth and poor outcome of patients with kidney cancer [28] [29].

The significance of NF- $\kappa \mathrm{B}$ pathway for complex and tissue-specific aspects of kidney cancer progression, such as metastasis, is less understood. In the absence of a functional VHL in clear cell carcinomas of kidney, the expression and activity of NF- $\kappa$ B are enhanced, which subsequently confer drug resistance [19] [30].

As researchers have learned more about the molecular and genetic changes in cells that cause cancer, they have developed newer drugs that target some of these changes. These targeted drugs are different from standard chemotherapy drugs. Until the development of targeted angiogenesis inhibitors, cytokine-based therapies such as interferon and high-dose interleukin 2 were the only systemic agents readily available despite limited clinical efficacy [31]. In summary, while HD IL-2 can result in a cure in metastatic RCC, given the significant toxicity and limited efficacy, its application is limited. So, targeted drugs are proving to be especially important in kidney cancer, where chemo- and cytokine therapy have not been shown to be very effective. Currently available oral tyrosine kinase inhibitors approved for treatment of metastatic RCC include sorafenib, sunitinib, pazopanib, and axitinib [32] [33]. But the common response to targeted drugs application is not high than $50 \%$. There is the fact molecular parameters changes at tyrosine kinase inhibitors therapy could determine its effectiveness [34]. Dornbusch J. (2013) have found expression of HIF-1 $\alpha$, VEGFR1 and -2 in the primary tumors of metastatic clear cell RCC patients might support the prediction of a good response to sunitinib treatment [35]. Rosa R., et al. (2013) have demonstrated that a panel of angiogenic proteins, such as HIF-1, VEGF expression, can correlate with the onset of resistance to sunitinib and the activity of everolimus in second line [36].

But the same studies with pazopanib influence on molecular markers of RCC are very little. Xu C.V. has shown the genetic association of HIF-1 $\alpha$ with response to pazopanib monotherapy [37]. So, search of molecular markers predicting the effectiveness of targeted therapy is actually for modern oncology.

The main reason of increased lethality of these patients is the cancer cell dissemination, which may appear at initial stages of cancer development. At present there are no significant clinical and molecular parameters that could predict disease's outcome and estimate the risk of metastasis appearance. The investigation of molecular mechanisms of kidney cancer metastasis development and search of additional significant prognostic factors is of great importance. The aim of study is to reveal associations between NF- $\kappa \mathrm{B}$, HIF-1alpha, VEGF expressions the proteasome and calpains activities, with tumor progression in patients with localized and disseminated kidney cancers and to find among molecular parameters, including transcription factors, VEGF, VEGFR2, m-TOR expressions and proteasome and calpain activity, parameters associated with the efficiency of pazopanib application in metastatic kidney cancer patients.

\section{Materials and Methods}

Patients. A homogenous group of 93 patients with RCC were enrolled complex combined treatment at Cancer Research Institute of Siberian Branch of Russian Academy of Medical Sciences, Tomsk, Russian Federation, from January 2008 to January 2014 (mean age $57.6 \pm 2.2$ years) and were selected for the present analysis. Localized kidney cancer (T1-3N0M0) was revealed in 50 patients. 43 patients have the disseminated form of disease (T2-4N0-1M1) - metastatic RCC. This group was divided into 2 subgroups: the first one was presented by 17 men with single kidney cancer metastasis; the second - by 26 men with multiple metastases. All patients with localized kidney cancers were enrolled the surgical treatment, which depending on the stage and location of the cancer was partial nephrectomy or simple nephrectomy. Diagnosis verification and estimation the cancer stage 
for 26 patients from subgroup 2 with metastatic RCC included the biopsy analysis. Their clinical characteristics are presented in Table 1 . The complex combined treatment of these men consisted of pre-operational pazopanib targeted therapy in dose of $800 \mathrm{mg}$ every day during the two months. At the end of therapy the response to treatment of patients was evaluated according the RECIST criteria and the radical nephrectomy was perfomed.

The study was approved by the Local Committee for Medical Ethics and all patients provided written informed consent. Specimens were reviewed by two pathologists separately. Investigation was performed in samples of cancer tissue. The frozen biopsy and operative cancer samples were stored at $-80^{\circ} \mathrm{C}$.

Preparing tissue homogenates. Tissue samples $(100 \mathrm{mg})$ were homogenized and then resuspended in $300 \mu \mathrm{L}$ of $50 \mathrm{mM}$ Tris-HCl buffer $(\mathrm{pH}=7.5)$ containing $2 \mathrm{mM} \mathrm{ATP,} 5 \mathrm{mM} \mathrm{MgCl}_{2}, 1 \mathrm{mM}$ dithiothreitol, $1 \mathrm{mM}$ EDTA, and $100 \mathrm{mM} \mathrm{NaCl}$. The homogenate was centrifuged at $10,000 \times \mathrm{g}$ for 60 minutes at $4^{\circ} \mathrm{C}$.

Preparing nuclear extract for HIF-1 $\alpha$ and NF- $\kappa B$ (p50 and p65) determination. The pellets left after preparing tissue homogenates were resuspended in $50 \mu \mathrm{L}$ of $50 \mathrm{mM}$ Tris- $\mathrm{HCl}$ buffer $(\mathrm{pH}=7.5)$ containing $2 \mathrm{mM}$ ATP, $5 \mathrm{mM} \mathrm{MgCl}_{2}, 1 \mathrm{mM}$ dithiothreitol, $1 \mathrm{mM}$ EDTA, and $100 \mathrm{mM} \mathrm{NaCl}$ and then centrifugated at 14,000 $\times \mathrm{g}$ for 10 minutes at $4^{\circ} \mathrm{C}$.

VEGF, VEGFR2, HIF-1 $\alpha, N F-\kappa B$ (p65 and p50) and p-m-TOR determination. HIF- $1 \alpha$, NF- $\kappa \mathrm{B}$ (p65 and p50) expressions were measured with Caymanchem ELISA kits (USA) in Anthos 2020 ELISA-microplate reader (Biochrom, UK). Nuclear extracts were prepared and purified according to manufacturer's instructions. Protein concentration in homogenates and nuclear extracts was determined by Lowry. VEGF, VEGFR2 and p-m-TOR were measured with R@D ELISA kits (USA). Results of VEGF, VEGFR2 and p-m-TOR levels measurements were expressed as pg per mg protein, while HIF- $1 \alpha$ and NF- $\kappa \mathrm{B}$ (p65 and p50) levels were expressed as relative light units per mg protein in well.

Proteasome fractiation. All procedures were carried out on ice or at $4^{\circ} \mathrm{C}$. Proteins from tissue homogenates were fractionated with stepwise concentrations of ammonium sulfate. 26S proteasome-rich fraction was isolated by adding ammonium sulphate to $40 \%$ final concentration, while $20 \mathrm{~S}$ proteasome-rich fraction was isolated by adding ammonium sulphate to $70 \%$ concentration [38]. The fractions were assayed for the proteasome activity.

Proteasome activity assay. Chymotrypsin-like activity of the total proteasome pool, of the 26S and the 20S pools was measured in cancer and non-transformed tissue homogenates, and in the proteasome fractions, using

Table 1. Clinical findings of 26 patients with disseminated RCC treated by pazopanib.

\begin{tabular}{|c|c|c|}
\hline \multirow{2}{*}{ parameters } & \multicolumn{2}{|c|}{ patients } \\
\hline & $n$ & $\%$ \\
\hline $\begin{array}{c}\text { Sex: } \\
\text { male } \\
\text { female }\end{array}$ & $\begin{array}{l}16 \\
10\end{array}$ & $\begin{array}{l}61.5 \\
38.5\end{array}$ \\
\hline $\begin{array}{c}\text { Mean age } \\
\text { (min-max), years }\end{array}$ & $\begin{array}{l}56 \pm 2.5 \\
(48-73)\end{array}$ & \\
\hline $\begin{array}{l}\text { T stage: } \\
\text { T1 } \\
\text { T2 } \\
\text { T3 } \\
\text { T4 }\end{array}$ & $\begin{array}{c}6 \\
10 \\
5 \\
5\end{array}$ & $\begin{array}{l}23.1 \\
38.5 \\
19.2 \\
19.2\end{array}$ \\
\hline $\begin{array}{l}\text { N stage: } \\
\text { N0 } \\
\text { N1 }\end{array}$ & $\begin{array}{c}19 \\
7\end{array}$ & $\begin{array}{l}73.1 \\
26.9\end{array}$ \\
\hline $\begin{array}{c}\text { Metastasis: } \\
\text { lung } \\
\text { bone } \\
\text { liver } \\
\text { contlateral adrenal } \\
\text { other organs }\end{array}$ & $\begin{array}{c}20 \\
11 \\
2 \\
1 \\
2\end{array}$ & $\begin{array}{c}76.9 \\
42.3 \\
7.6 \\
3.8 \\
7.6\end{array}$ \\
\hline $\begin{array}{c}\text { MSKCC prognosis: } \\
\text { good } \\
\text { intermediate } \\
\text { poor }\end{array}$ & $\begin{array}{c}10 \\
14 \\
2\end{array}$ & $\begin{array}{c}38.5 \\
53.4 \\
7.8\end{array}$ \\
\hline
\end{tabular}


the fluorogenic substrate N-Succinyl-Leu-Leu-Val-Tyr-7-Amido-4-Methylcoumarin (Suc-LLVY-AMC) in a Hitachi-850 (Japan) fluorimeter at an excitation wavelength of $380 \mathrm{~nm}$ and an emission of $440 \mathrm{~nm}$. This substrate is preferentially hydrolyzed by the chymotrypsin-like peptidase activity of the 20S proteasome [39]. The $20 \mathrm{~S}$ proteasome activity solution contained $20 \mathrm{mM}$ Tris- $\mathrm{HCl}(\mathrm{pH}=7.5), 1 \mathrm{mM}$ dithiothreitol, and $30 \mu \mathrm{M}$ Suc-LLVY-AMC. The 26S proteasome activity solution additionally contained $5 \mathrm{mM} \mathrm{MgCl}_{2}$ and $1 \mathrm{mM}$ ATP. The reaction was carried out for 20 minutes at $37^{\circ} \mathrm{C}$ and then was stopped by the addition of $1 \%$ sodium dodecyl sulfate. We used the proteasome inhibitor MG-132 to estimate the influence of other proteases. The unit of activity per mg protein was calculated. Protein concentration was determined by Lowry.

Calpains activity assay. The calpains activity was performed in tissue homogenates using the fluorogenic substrate N-Succinyl-Leu-Leu-Val-Tyr-7-Amido-4-Methylcoumarin (Suc-LLVY-AMC) in a Hitachi-850 (Japan) fluorimeter at an excitation wavelength of $380 \mathrm{~nm}$ and an emission of $440 \mathrm{~nm}$ [40].

The calpains activity solution contained $100 \mathrm{mM}$ Tris- $\mathrm{HCl}(\mathrm{pH}=7.3), 145 \mathrm{mM} \mathrm{NaCl}$ and $30 \mu \mathrm{M}$ Suc-LLVYAMC. Incubations were performed at room temperature for 30 minutes in absence or presence of $10 \mathrm{mM} \mathrm{CaCl}_{2}$ and $0.1 \mathrm{mM}$ N-Acetyl-L-leucyl-L-leucyl-L-norleucinal (calpain inhibitor I). The reaction was stopped by the addition of $1 \%$ sodium dodecyl sulfate. Calpains activity was measured as fluorogenic units per mg protein. Protein concentration was determined by Lowry.

Statistical analysis. Statistical analysis was performed using Statistica 8.0 Software. Normally distributed data are expressed as mean \pm s.e.d, otherwise data are expressed as median (interquartile ranges). To evaluate the difference, either the Student t test or the Mann-Whitney test was applied. Correlation analysis on data was carried out with Spearman Rank Correlation test. Multivariate discriminate analysis was performed during the investigation. The level of significance was set at $P<0.05$.

\section{Results and Discussion}

$N F-\kappa B, H I F-1 a l p h a, V E G F$ expressions in RCC. The results of NF- $\kappa \mathrm{B}$, HIF-1alpha, VEGF expressions the proteasome and calpains activities in localized and disseminated kidney cancer tissues are presented in Table 2. The level of NF- $\kappa \mathrm{B}$ p65 is higher in tumors with hematogenic metastases in comparison to the localized form of disease. The changes of NF- $\kappa \mathrm{B}$ p50 content are not revealed. The ratio of NF- $\kappa \mathrm{B}$ p65 relative to NF- $\kappa \mathrm{B}$ p50 less then 1.0 is the sign of nonactive dimmers of NF $\kappa B$ (Conner J.R. 2010). Coefficient NF- $\kappa B$ p65/p50 has the complex wave-like dynamic: it is high in cancers of patients with single metastasis (3.0 (1.6 - 3.0)) and is decreased in tumors of patients with multiple metastases $(0.92(0.83-1.07))$, reaching the level of patients with localized disease $(0.6$ ( $0.3-2.0)$. According to the obtained results we suppose that coefficient NF- $\kappa \mathrm{B}$ p65/p50 may by concerned as kidney cancer progression criteria.

At next step of research we have studied the changes of HIF-1 and VEGF expressions in tumors with localized and metastatic kidney cancers. Content of HIF-1 is increased in cancers of patients with single and multiple metastases. Probably, increased HIF-1 expression is stimulated the VEGF production at initial stage of on-

Table 2. NF- $\kappa$ B p65, NF- $\kappa$ B p50, HIF- $1 \alpha$ and VEGF expressions in RCC tissues.

\begin{tabular}{|c|c|c|c|c|c|c|}
\hline \multicolumn{2}{|c|}{ Groups } & \multirow{2}{*}{$\begin{array}{c}\text { NF- } k \text { B p65 } \\
\text { expression, RLU } \\
\text { per protein in well } \\
\\
5.0 \\
(2.0-7.9)\end{array}$} & \multirow{2}{*}{$\begin{array}{c}\text { NF- } \kappa \text { B p50 } \\
\text { expression, RLU } \\
\text { per protein in well } \\
6.4 \\
(3.3-10.0)\end{array}$} & \multirow{2}{*}{$\begin{array}{c}\text { Coefficient } \\
\text { NF- } \kappa \text { B p65/p50 } \\
0.6 \\
(0.3-2.0)\end{array}$} & \multirow{2}{*}{$\begin{array}{l}\text { HIF-1 expression, } \\
\text { RLU per } \\
\text { protein in well } \\
4.2 \\
(2.2-7.8)\end{array}$} & \multirow{2}{*}{$\begin{array}{c}\text { VEGF expression, } \\
\text { pg/per mg } \\
\text { of protein } \\
71.5 \\
71.5-139.7)\end{array}$} \\
\hline $\begin{array}{c}\text { Localized } \\
\text { kidney cancer }\end{array}$ & $\mathrm{T}_{1-3} \mathrm{~N}_{0} \mathrm{M}_{0}$ & & & & & \\
\hline \multirow{2}{*}{$\begin{array}{l}\text { Disseminated } \\
\text { kidney cancer }\end{array}$} & $\begin{array}{c}\mathrm{T}_{2-4} \mathrm{~N}_{0-1} \mathrm{M}_{1} \\
\text { (subgroup 1, } \\
\text { with single } \\
\text { metastasis) }\end{array}$ & $\begin{array}{c}11.3 \\
(6,8-15,7)^{*}\end{array}$ & $\begin{array}{c}6.2 \\
(4.4-9.7)\end{array}$ & $\begin{array}{c}3.0 \\
(1.6-3.0)^{*}\end{array}$ & $\begin{array}{c}7.9 \\
(6.2-8.5)^{*}\end{array}$ & $\begin{array}{c}205.4 \\
(131.7-261.5)^{*}\end{array}$ \\
\hline & $\begin{array}{c}\mathrm{T}_{2-4} \mathrm{~N}_{0-1} \mathrm{M}_{1} \\
\text { (subgroup 2, } \\
\text { with multiple } \\
\text { metastases) }\end{array}$ & $\begin{array}{c}11.5 \\
(6.7-32.5)^{*}\end{array}$ & $\begin{array}{c}10.6 \\
(6.3-37.7)\end{array}$ & $\begin{array}{c}0.92 \\
(0.83-1.07)^{* *}\end{array}$ & $\begin{array}{c}18.7 \\
(4.2-19.4)^{* * *}\end{array}$ & $\begin{array}{c}26.8 \\
(11.0-99.2)^{* * *}\end{array}$ \\
\hline
\end{tabular}

Note: The results represent the Me (Q1 - Q3); ${ }^{*}$ in comparison with $\mathrm{T}_{1-3} \mathrm{~N}_{0} \mathrm{M}_{0}$ group, $p<0.05 ;{ }^{* *}$ in comparison with $\mathrm{T}_{2-4} \mathrm{~N}_{1} \mathrm{M}_{1}(\mathrm{disseminated}$ kidney cancer: subgroup 1, with single metastasis); group, $p<0.05$; 
cogenesis already. We have found the VEGF over expression in 2.87 fold in patients with single metastasis in comparison to the tumors of patients without it. Additionally the multiple metastasis development is associated with the decrease of VEGF content. The results indicate that tumor tissue of kidney cancer liberates VEGF into the systemic blood flow [41]. It is important to note that similar VEGF expression and NF- $\kappa$ B p65/ p50 changes are associated with the metastasis development.

Proteasome and calpain activity in RCC. During the analysis of proteasome and calpain activities we have shown the decrease of proteasome activity in cancers of patients with disseminated disease in 1.33 and 1.36 fold, consequently, in comparison to the localized cancer ones (Table 3). The changes of calpain activity have the wave-like dependent on cancer progression. Thus, the increased calpain activity is found at the initial stage of cancer metastasis development. The further disease progression is combined with fall of calpain activity in cancer tissues of metastatic RCC patients (in subgroup 1 in 4.4 fold and in subgroup 2-in 5.88 fold in comparison to the localized kidney cancers). According to the similar one-way changes of VEGF expression and calpain activity, we suppose the role of these enzymes in VEGF level regulation. At present it is known the role of calpain in cell protein degradation, which is wide presented in absence of proteasome or in case of its decreased activity [26]. Besides, calpains take part in activation of cancer cell locomotion [42]. Perhaps, this fact may be explained with its role in hematogenic metastasis development of kidney cancer patients.

The study of transcription and growth factors expressions and estimation their regulating proteolysis in kidney cancer tissues of patients with localized and disseminated forms of disease allow us to confess their role in oncogenesis. The expressed contents of NF- $\kappa$ B, HIF-1 and VEGF are found at initial stages of metastasis development. At the same time we have revealed the growth of calpain activity and decreased proteasome activity. At next stages of oncogenesis it is obtained the decrease of NF- $\kappa \mathrm{B}$ active forms, VEGF expression and fall of calpain activity. Association of transcription and growth factors expressions with cellular proteases activities and cancer spreading is the basis for new molecular prognostic factors search. The next aim of our research is to find molecular markers, associated with the targeted therapy efficiency and response. We have widen the panel of molecular parameters and included in it p-m-TOR expression-the key serin/threonin protease and VEGFR2 content.

The main goal of our research was to find molecular markers associated with the efficiency of pazopanib targeted therapy in metastatic kidney cancer patients. We have included in this panel the expression of transcription factors NF- $\kappa$ B p65, NF- $\kappa$ B p50, HIF-1, growth factor VEGF, VEGFR2 and protease p-m-TOR and estimate their levels before and after the targeted therapy.

Association of transcription factors, VEGF, VEGFR2 and p-m-TOR expressions with response to pazopanib therapy of metastatic RCC patients. The partial kidney cancer regression is revealed in $29.6 \%$ of patients treated by pazopanib, cancer stabilization - in $61.5 \%$ of patients and cancer progression - in 11.5\% of patients (Table 4). According to clinical response to pazopanib application two groups of metastatic RCC patients are perfomed. The first one is consisted of patients with partial cancer regression or stabilization, the second one-patients with cancer progression.

It is revealed the high levels of NF- $\kappa \mathrm{B}$ p65, NF- $\kappa \mathrm{B}$ p50, HIF-1 and VEGF in cancers of patients with response to pazopanib therapy (group 1-patients with partial regression and cancer stabilization) in comparison to the patients with cancer progression (group 2) (Table 5). After pazopanib therapy it is obtained the decrease of NF- $\kappa$ B p50, HIF-1 and VEGF expressions in 2.9; 4.5 and 4.1 fold, consequently, in comparison to the same

Table 3. Proteasome and calpain activities in kidney cancer tissues.

\begin{tabular}{|c|c|c|c|}
\hline & Groups & $\begin{array}{l}\text { Proteasome activity, } \\
1000 \mathrm{ME} / \text { per mg protein }\end{array}$ & $\begin{array}{l}\text { Calpains activity, } \\
1000 \mathrm{ME} / \text { per mg protein }\end{array}$ \\
\hline $\begin{array}{l}\text { Localized kidney } \\
\text { cancer }\end{array}$ & $\mathrm{T}_{1-3} \mathrm{~N}_{0} \mathrm{M}_{0}$ & $36.1(20.0-102.0)$ & $33.5(16.8-33.5)$ \\
\hline \multirow{2}{*}{$\begin{array}{l}\text { Disseminated } \\
\text { kidney cancer }\end{array}$} & $\begin{array}{c}\mathrm{T}_{2-4} \mathrm{~N}_{0-1} \mathrm{M}_{1} \\
\text { (subgroup 1, with single metastasis) }\end{array}$ & $27.0(5.5-43.1)^{*}$ & $44.7(18.6-54.3)^{*}$ \\
\hline & $\begin{array}{c}\mathrm{T}_{2-4} \mathrm{~N}_{0-1} \mathrm{M}_{1} \\
\text { (subgroup 2, with multiple metastases) }\end{array}$ & $26.4(4.1-50.0)^{*}$ & $7.6(4.1-22.2)^{* * * *}$ \\
\hline
\end{tabular}

Note: The results represent the Me (Q1 - Q3); ${ }^{*}$ in comparison with $\mathrm{T}_{1-3} \mathrm{~N}_{0} \mathrm{M}_{0}$ group, $p<0.05 ;{ }^{* *}$ in comparison with $\mathrm{T}_{2-4} \mathrm{~N}_{1} \mathrm{M}_{1}$ (disseminated kidney cancer: subgroup 1, with single metastasis); group, $p<0.05$. 
Table 4. Effectiveness of pazopanib treatment of RCC patients according RECIST criteria.

\begin{tabular}{cccc}
\hline & & Patients & \\
Cancer response & $\mathrm{n}$ & 0 \\
\cline { 2 - 4 } & & 0 & 26.9 \\
Full regression & 7 & 61.65 \\
Partial regression & 16 & 11.45 \\
Cancer stabilization & 3 & & 0 \\
\hline
\end{tabular}

Table 5. NF- $\kappa$ B p65, NF- $\kappa$ B p50, HIF-1 $\alpha$, VEGF, VEGFR2 and p-m-TOR expressions in RCC patients treated with pazopanib (group 1-partial regression and stabilization, group 2 - cancer progression).

\begin{tabular}{|c|c|c|c|c|c|c|c|c|c|c|c|c|}
\hline \multirow[b]{2}{*}{ Group } & \multicolumn{2}{|c|}{$\begin{array}{c}\text { NF- } \kappa \mathrm{B} \text { p65 } \\
\text { expression, } \\
\text { RLU per protein } \\
\text { in well }\end{array}$} & \multicolumn{2}{|c|}{$\begin{array}{l}\text { NF- } \kappa \text { B p50 } \\
\text { expression, } \\
\text { RLU per protein } \\
\text { in well }\end{array}$} & \multicolumn{2}{|c|}{$\begin{array}{l}\text { HIF-1 expression, RLU } \\
\text { per } \\
\text { protein in well }\end{array}$} & \multicolumn{2}{|c|}{$\begin{array}{l}\text { p-m-TOR } \\
\text { expression, } \\
\text { pg/per mg } \\
\text { of protein }\end{array}$} & \multicolumn{2}{|c|}{$\begin{array}{l}\text { VEGF expression, } \\
\text { pg/per mg } \\
\text { of protein }\end{array}$} & \multicolumn{2}{|c|}{$\begin{array}{l}\text { VEGFR2 } \\
\text { expression, pg/per } \\
\text { mg of protein }\end{array}$} \\
\hline & $\begin{array}{l}\text { Before } \\
\text { therapy }\end{array}$ & $\begin{array}{l}\text { After } \\
\text { therapy }\end{array}$ & $\begin{array}{l}\text { Before } \\
\text { therapy }\end{array}$ & $\begin{array}{l}\text { After } \\
\text { therapy }\end{array}$ & $\begin{array}{l}\text { Before } \\
\text { therapy }\end{array}$ & $\begin{array}{l}\text { After } \\
\text { therapy }\end{array}$ & $\begin{array}{l}\text { Before } \\
\text { therapy }\end{array}$ & After therapy & $\begin{array}{l}\text { Before } \\
\text { therapy }\end{array}$ & $\begin{array}{l}\text { After } \\
\text { therapy }\end{array}$ & $\begin{array}{l}\text { Before } \\
\text { therapy }\end{array}$ & $\begin{array}{l}\text { After } \\
\text { therapy }\end{array}$ \\
\hline 1 & $\begin{array}{c}10.8 \\
(7.3-15.4)\end{array}$ & $\begin{array}{c}10.85 \\
(7.3-15.37)\end{array}$ & $\begin{array}{c}14.0 \\
(6.34-20.6)\end{array}$ & $\begin{array}{c}4.8 \\
(3.77- \\
9.26)^{\#}\end{array}$ & $\begin{array}{c}6.55 \\
(5.55-9.91)\end{array}$ & $\begin{array}{c}1.45 \\
(0.54-2.8)^{\#}\end{array}$ & $\begin{array}{c}14.0 \\
(0.0-15.7)\end{array}$ & $\begin{array}{c}4.15 \\
(1.74-14.8)^{\#}\end{array}$ & $\begin{array}{c}38.2 \\
(11.0-52.5)\end{array}$ & $\begin{array}{c}9.2 \\
(7.7-13.1)^{\#}\end{array}$ & $\begin{array}{c}43.3 \\
(23.5-50.0)\end{array}$ & $\begin{array}{c}32.2 \\
(19.0-108.6)\end{array}$ \\
\hline 2 & $\begin{array}{c}3.9 \\
(3.44-4.43)^{*}\end{array}$ & $\begin{array}{c}3.93 \\
*(3.4-4.43)\end{array}$ & $\begin{array}{c}4.8 \\
(4.5-5.12)^{*}\end{array}$ & $\begin{array}{c}2.9 \\
(2.18-3.8)\end{array}$ & $\begin{array}{c}3.5 \\
(2.5-4.67)^{*}\end{array}$ & $\begin{array}{c}0.56 \\
(0.13-1.0)\end{array}$ & $\begin{array}{c}11.6 \\
(11.1-12.2)\end{array}$ & $\begin{array}{c}6.37 \\
(2.89-9.85)\end{array}$ & $\begin{array}{c}9.8 \\
(8.6-11.1)^{*}\end{array}$ & $\begin{array}{c}10.6 \\
(8.8-12.4)\end{array}$ & $\begin{array}{c}53,9 \\
(33.5-74.2)\end{array}$ & $\begin{array}{c}24.0 \\
(19.1-28.9)\end{array}$ \\
\hline
\end{tabular}

Note: The results represent the Me (Q1 - Q3); ${ }^{*}$ in comparison with group $1, p<0.05 ;{ }^{*}$ in comparison with group of patients before preoperative pazopanib therapy, $p<0.05$.

markers before treatment. It is noted the VEGFR2 content is the same in all groups of patients and not change during the targeted therapy.

The influence of pazopanib targeted therapy on p-m-TOR expression is found in cancers of patients with response to it (group 1). The level of protein is decreased in 3.37 fold during the treatment.

The received data confirm the connection between the response to pazopanib therapy and cancer molecular markers and allow us to suppose them as additional criteria, predicting the efficiency of targeted therapy.

Association of proteasome and calpain activities with response to pazopanib therapy of metastatic RCC patients. The changes of proteasome and calpain activities are found in metastatic RCC undergoing the pazopanib therapy (Figure 1). During the targeted therapy it is revealed the decrease of proteasome activity and growth of calpain activity in 1.66 and 12.6 fold in cancers of patients with partial regression and stabilization. Pazopanib inefficiency is correlated with the increase of protease activity in tumor of patients with cancer progression after targeted therapy. Probably, the effective pazopanib application has been associated with the low level of proteasome substrates in kidney cancers. We have found development of drugs inefficiency leads to cellular proteolysis activation.

\section{Conclusion}

So, it is revealed that the effective pazopanib application in metastatic kidney cancer patients is associated with the high levels of transcription factors NF- $\kappa \mathrm{B}$, HIF-1 and growth factor VEGF, increased proteasome activity before targeted therapy. The significant decrease of studied parameters has been found in tumors after the treatment. This fact allows us to consider these molecular markers as predicting criteria of targeted therapy efficiency. The results of investigation will be able to optimize the therapy of metastatic kidney cancer patients and will improve treatment outcome.

\section{Acknowledgements}

This study was supported by the President Grant No. MD-3637.2015.7 


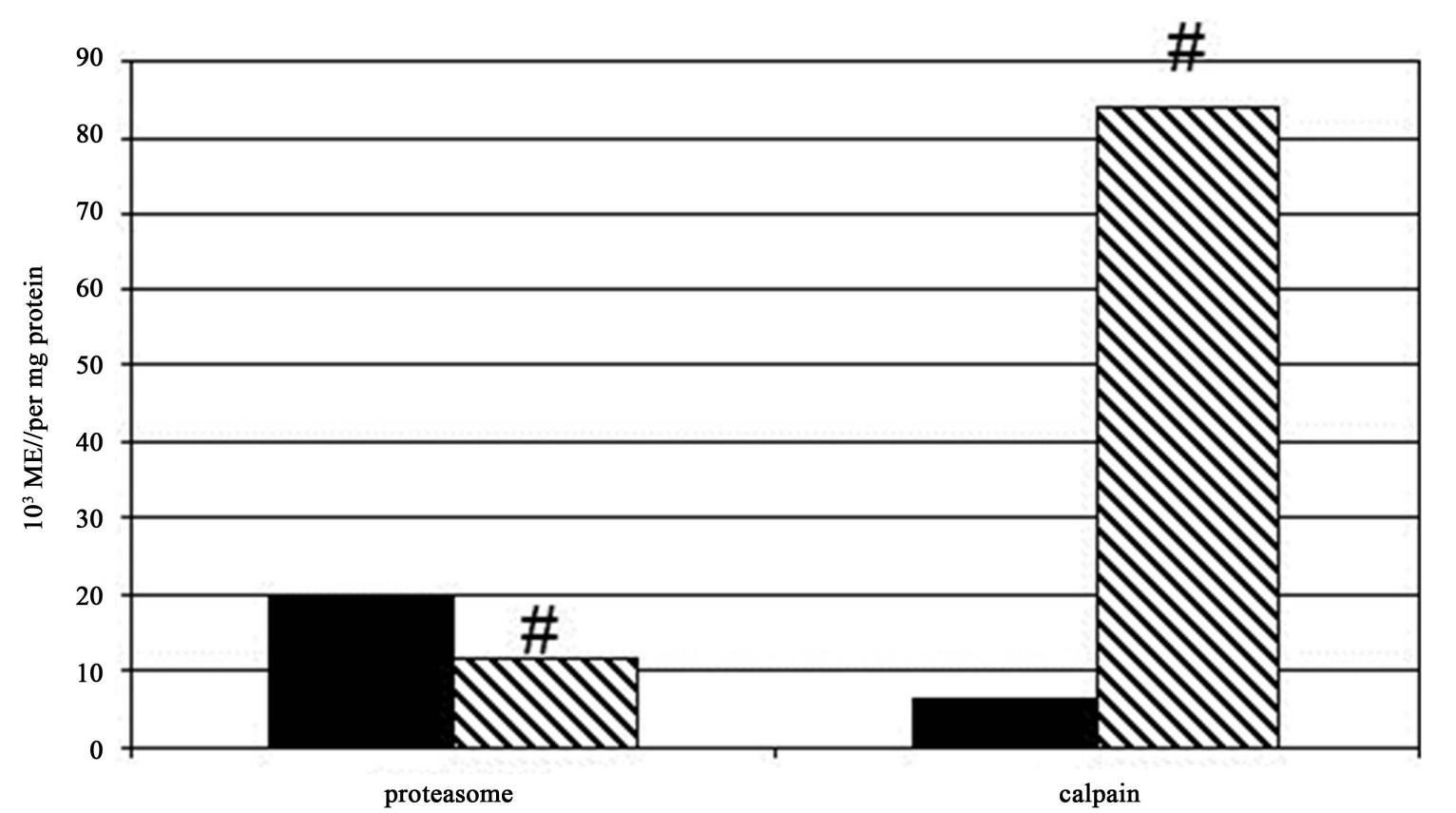

before targeted therapy

$\mathbf{\nabla}$ after targeted therapy

(a)

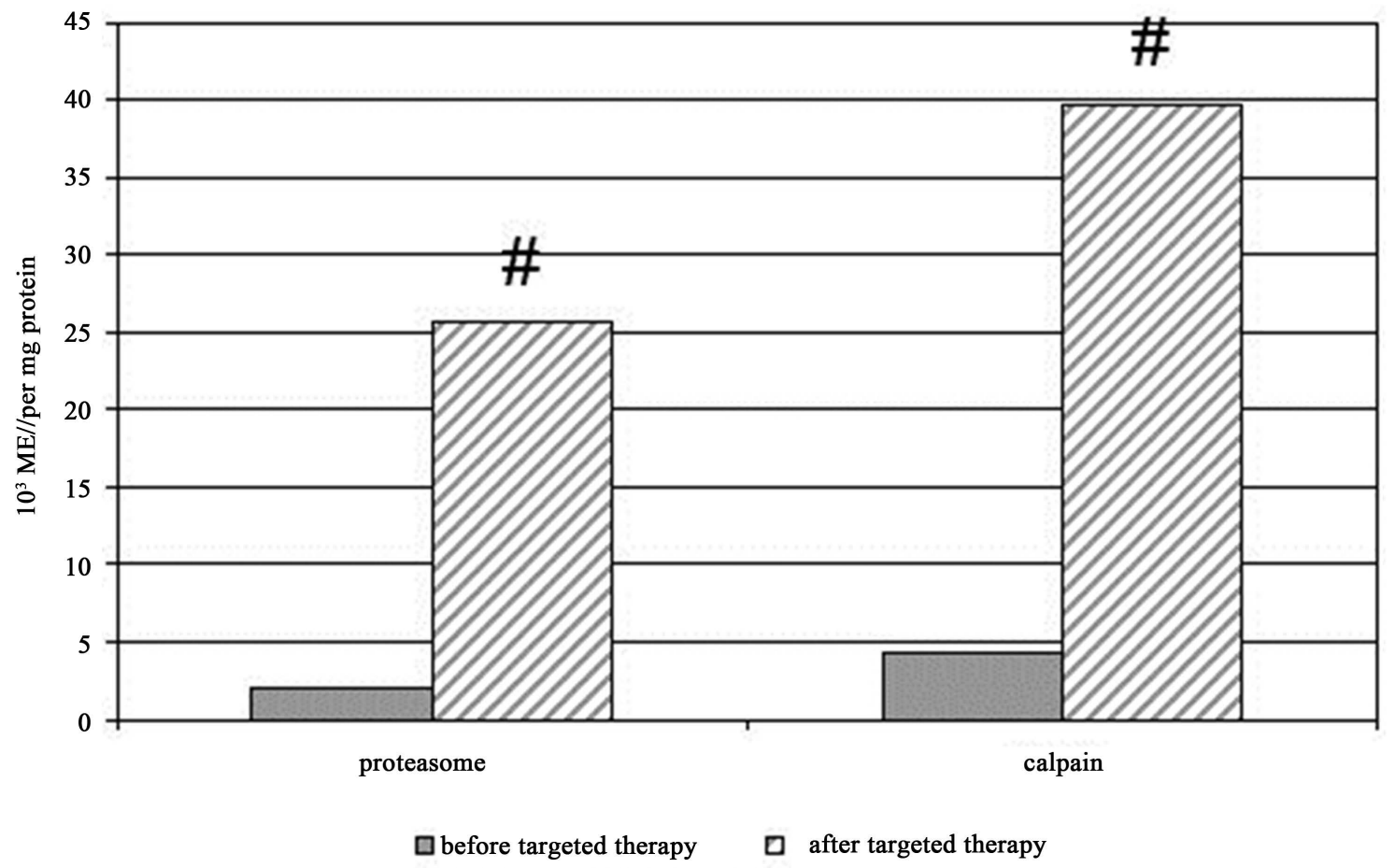

(b)

Figure 1. Proteasome and calpain activities in RCC patients with response to pazopanib therapy (group 1) (a) and cancer

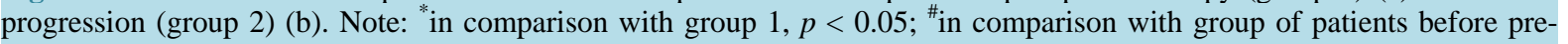
operative pazopanib therapy, $p<0.05$. During the targeted therapy it was revealed the decrease of proteasome activity and growth of calpain activity in 1.66 and 12.6 fold in cancers tissues of patients with partial regression and stabilization (group 1). Pazopanib inefficiency was correlated with the increase of protease activity in tumor of patients with cancer progression after targeted therapy. 


\section{Conflict}

The authors declare that they have no conflict of interest.

\section{References}

[1] Kidney Cancer (2014) Cancer.Net Editorial Board. http://www.cancer.net/cancer-types/kidney-cancer/statistics

[2] Kidney Cancer (2014) National Cancer Institute at the National Institutes of Health. http://www.cancer.gov/cancertopics/types/kidney

[3] Keefe, S.M., Nathanson, K.L. and Rathmell, W.K. (2013) The Molecular Biology of Renal Cell Carcinoma. Seminars in Oncology, 40, 421-428. http://dx.doi.org/10.1053/j.seminoncol.2013.05.006

[4] Na, X., Wu, G., Ryan, C.K., Schoeb, S.R., di’Santagnese, P.A. and Messing, E.M. (2003) Overproduction of Vascular Endothelial Growth Factor Related to von Hippel-Lindau Tumor Suppressor Gene Mutations and Hypoxia-Inducible Factor-1 $\alpha$ Expression in Renal Cell Carcinomas. Journal of Urology, 170, 588-592.

http://dx.doi.org/10.1097/01.ju.0000074870.54671.98

[5] Hoffmann, A. and Baltimore, D. (2006) Circuitry of Nuclear Factor $\kappa$ B Signaling. Immunological Reviews, 210, 171186.

[6] Zhou, J., Kohl, R., Herr, B., Frank, R. and Brune, B. (2006) Calpain Mediates a von Hippel-Lindau Protein-Independent Destruction of Hypoxia-Inducible Factor-1 $\alpha$. Molecular Biology of the Cell, 17, 1549-558.

http://dx.doi.org/10.1091/mbc.E05-08-0770

[7] Klatte, T., Seligson, D.B., Riggs, S.B., Leppert, J.T. and Berkman, M.K. (2007) Hypoxia-Inducible Factor-1 $\alpha$ in Clear Cell Renal Cell Carcinoma. Clinical Cancer Research, 13, 7388-7393. http://dx.doi.org/10.1158/1078-0432.CCR-07-0411

[8] Goldberg, A.L. (2007) Functions of the Proteasome: From Protein Degradation and Immune Surveillance to Cancer Therapy. Biochemical Society Transactions, 35, 12-17. http://dx.doi.org/10.1042/BST0350012

[9] Kostadinova, R.M., Nawrocki, A.R., Frey, F.J. and Frey, B.M. (2005) Tumor Necrosis Factor $\alpha$ and Phorbol 12-Myristate-13-acetate Down-Regulate Human 11 $\beta$-Hydroxysteroid Dehydrogenase Type 2 through p50/p50 NF- $\kappa$ B Homodimers and Egr-1. FASEB Journal, 19, 650-652.

[10] Marui, N., Medford, R.M. and Ahmad, M. (2005) Activation of RelA Homodimers by Tumor Necrosis Factor $\alpha$ : A Possible Transcriptional Activator in Human Vascular Endothelial Cells. Biochemical Journal, 390, 317-324. http://dx.doi.org/10.1042/BJ20041659

[11] Juvekar, A.S., Manna, S., Ramaswami, S., Chang, T.P., Vu, H.Y., Ghosh, C.C., Celiker, M.Y. and Vancurova, I. (2011) Bortezomib Induces Nuclear Translocation of $\mathrm{IkB} \alpha$ Resulting in Gene-Specific Suppression of NF- $\kappa \mathrm{B}-$ Dependent Transcription and Induction of Apoptosis in CTCL. Molecular Cancer Research, 9, 183-194. http://dx.doi.org/10.1158/1541-7786.MCR-10-0368

[12] Conner, J.R., Smirnova, I.I., Moseman, A.P. and Poltorak, A. (2010) IRAK1BP1 Inhibits Inflammation by Promoting Nuclear Translocation of NF- $\kappa$ Bp50. Proceedings of the National Academy of Sciences of the United States of America, 107, 11477-11482. http://dx.doi.org/10.1073/pnas.1006894107

[13] van Uden, P., Kenneth, N.S. and Rocha, S. (2008) Regulation of Hypoxia-Inducible Factor- $1 \alpha$ by NF- $\kappa$ B. Biochemical Journal, 412, 477-484.

[14] Baldwin, A.S. (1996) The NF- $\kappa$ B and I $\kappa$ B Proteins: New Discoveries and Insights. Annual Review of Immunology, 14, 649-683. http://dx.doi.org/10.1146/annurev.immunol.14.1.649

[15] Kelvin, J.A.D. and Reshma, S. (2006) Preferential Degradation of Oxidized Proteins by the 20S Proteasome May Be Inhibited in Aging and in Inflammatory Neuromuscular Diseases. Neurology, 66, 93-96. http://dx.doi.org/10.1212/01.wnl.0000192308.43151.63

[16] Sorokin, A.V., Kim, E.R. and Ovchinnikov, L.P. (2009) Proteasome System of Protein Degradation and Processing. Biochemistry (Moscow), 74, 1411-1442. http://dx.doi.org/10.1134/S000629790913001X

[17] Chen, C., Seth, A.K. and Aplin, A.E. (2006) Genetic and Expression Aberrations of E3 Ubiquitin Ligases in Human Breast Cancer. Molecular Cancer Research, 4, 695-707. http://dx.doi.org/10.1158/1541-7786.MCR-06-0182

[18] Voutsadakis, I.A. (2007) Pathogenesis of Colorectal Carcinoma and Therapeutic Implications: The Role of the Ubiquitin-Proteasome System and Cox-2. Journal of Cellular and Molecular Medicine, 11, 252-337. http://dx.doi.org/10.1111/j.1582-4934.2007.00032.x

[19] An, J. and Rettig, M.B. (2005) Mechanism of Von Hippel-Lindau Protein-Mediated Suppression of Nuclear Factor Kappa B Activity. Molecular and Cellular Biology, 25, 7546-7556. http://dx.doi.org/10.1128/MCB.25.17.7546-7556.2005 
[20] An, J. and Rettig, M.B. (2007) Epidermal Growth Factor Receptor Inhibition Sensitizes Renal Cell Carcinoma Cells to the Cytotoxic Effects of Bortezomib. Molecular Cancer Therapeutics, 6, 61-69. http://dx.doi.org/10.1158/1535-7163.MCT-06-0255

[21] Spirina, L.V., Kondakova, I.V., Usynin, Y.A. and Vintizenko S.I. (2008) Angiogenesis Regulation in Renal and Bladder Cancers. Siberian Journal of oncology, 4, 65-70.

[22] Wu, W.K., Volta, V., Cho, C.H., Wu, Y.C., Li, H.T., Yu, L., Li, Z.J. and Sung, J.J. (2009) Repression of Protein Translation and mTOR Signaling by Proteasome Inhibitor in Colon Cancer Cells. Biochemical and Biophysical Research Communications, 386, 598-601. http://dx.doi.org/10.1016/j.bbrc.2009.06.080

[23] Li, C., Chen, S., Yue, P., Deng, X., Lonial, S., Khuri, F.R. and Sun, S.Y. (2010) Proteasome Inhibitor PS-341 (Bortezomib) Induces Calpain-Dependent $\mathrm{I} \kappa \mathrm{B} \alpha$ Degradation. Journal of Biological Chemistry, 285, 16096-16104. http://dx.doi.org/10.1074/jbc.M109.072694

[24] Moorty, A.K., Savinova, O.V., Ho, J.Q., Wang, V.Y., Vu, D. and Ghosh, G. (2006) The 20S Proteasome Processes NF- $\kappa$ B1 p105 into p50 in a Translation-Independent Manner. The EMBO Journal, 25, 1945-1956. http://dx.doi.org/10.1038/sj.emboj.7601081

[25] Sorimachi, H., Hata, S. and Ono, Y. (2011) Calpain Chronicle an Enzyme Family under Multidisciplinary Characterization. Proceedings of the Japan Academy, Series B, 87, 287-327. http://dx.doi.org/10.2183/pjab.87.287

[26] Smith, I.J. and Dodd, S.L. (2007) Calpain Activation Causes a Proteasome Dependent Increase in Protein Degradation and Inhibits the Akt Signaling Pathway in Rat Diaphragm Muscle. Experimental Physiology, 92, 561-573. http://dx.doi.org/10.1113/expphysiol.2006.035790

[27] Yagasaki, H., Kawata, N., Takimoto, Y. and Nemoto, N. (2003) Histopathological Analysis of Angiogenic Factors in Renal Cell Carcinoma. International Journal of Urology, 10, 220-227.

[28] Spirina, L.V., Kondakova, I.V., Usynin, E.A. and Yurmazov, Z.A. (2012) Expression Regulation of Transcription Factors and Endothelial Growth Factor by Proteosomal System in Patients with Metastatic Renal Carcinoma. Journal of N. N. Blokhin Russian Cancer Research Center, 23, 27-32.

[29] Lidgren, A., Hedberg, Y., Grankvist, K., Rasmuson, T., Vasko, J. and Ljungberg, B. (2005) The Expression of Hypoxia-Inducible Factor $1 \alpha$ Is a Favorable Independent Prognostic Factor in Renal Cell Carcinoma. Clinical Cancer Research, 11, 1129-1135.

[30] Morais, C., Gobe, G., Johnson, D.W. and Healy, H. (2011) The Emerging Role of Nuclear Factor Kappa B in Renal Cell Carcinoma. The International Journal of Biochemistry \& Cell Biology, 43, 1537-1549. http://dx.doi.org/10.1016/j.biocel.2011.08.003

[31] Atkins, M., Regan, M. and McDermott, D. (2004) Update on the Role of Interleukin 2 and Other Cytokines in the Treatment of Patients with Stage IV Renal Carcinoma. Clinical Cancer Research, 10, 6342S-6346S. http://dx.doi.org/10.1158/1078-0432.ccr-040029

[32] Guerin, M., Salem, N., Walz, J., Dermeche, S. and Gravis, G. (2013) Major Response with Sorafenib in Advanced Renal Cell Carcinoma after 14 Years of Follow-Up. World Journal of Surgical Oncology, 11, 243-247. http://dx.doi.org/10.1186/1477-7819-11-243

[33] Levy, A., Hollebecque, A., Ferte, C., Koscielny, S., Fernandez, M., Soria, J.-C. and Massard, C. (2013) Tumor Assessment Criteria in Phase I Trials: Beyond RECIST. Journal of Clinical Oncology, 31, 395. http://dx.doi.org/10.1200/JCO.2012.46.2184

[34] Hugonnet, F., Fournier, L., Medioni, J., Smadja, C., Hindie, E., Huchet, V., Itti, E., Cuenod, C.-A., Chatellier, G., Oudard, S. and Faraggi, M. (2011) Metastatic Renal Cell Carcinoma: Relationship between Initial Metastasis Hypoxia, Change after 1 Month's Sunitinib, and Therapeutic Response: An 18F-Fluoromisonidazole PET/CT Study. Journal of Nuclear Medicine, 52, 1048-1055. http://dx.doi.org/10.2967/jnumed.110.084517

[35] Dornbusch, J., Zacharis, A., Meinhardt, M., Erdmann, K. and Wolff, I. (2013) Analyses of Potential Predictive Markers and Survival Data for a Response to Sunitinib in Patients with Metastatic Renal Cell Carcinoma. PLoS ONE, 8, e76386. http://dx.doi.org/10.1371/journal.pone.0076386

[36] Rosa, R., Damiano, V., Nappi, L., Formisano, L., Massari, F., Scarpa, A., Martignoni, G., Bianco, R. and Tortora, G. (2013) Angiogenic and Signalling Proteins Correlate with Sensitivity to Sequential Treatment in Renal Cell Cancer. British Journal of Cancer, 109, 686-693. http://dx.doi.org/10.1038/bjc.2013.360

[37] Xu, C.V., Bing, N.X., Ball, H.A., Rajagopalan, D., Sternberg, C.N., Hutson, T.E., de Souza, P., Xue, Z.G., McCann, L., King, K.S., Ragone, L.J., Whittaker, J.C., Spraggs, C.F., Cardon, L.R., Mooser, V.E. and Pandite, L.N. J. (2011) Pazopanib Efficacy in Renal Cell Carcinoma: Evidence for Predictive Genetic Markers in Angiogenesis-Related and Exposure-Related Genes. Journal of Clinical Oncology, 29, 2557-2564. http://dx.doi.org/10.1200/JCO.2010.32.9110

[38] Abramova, E.B., Astakhova, T.M., Erokhov, P.A. and Sharova, N.P. (2004) Multiple Forms of the Proteasomes and Some Approaches to Their Separation. Izvestiya Akademii Nauk-Seriya Biologicheskaya, 2, 150-156. 
[39] Ben-Shahar, S., Komlosh, A., Nadav, E., Shaked, I., Ziv, T., Admon, A., Martino, G.N. and Ress, Y. (1999) 26S Proteasome-Mediated Production of an Authentic Major Histocompatibility Class I-Restricted Epitope from an Intact Protein Substrate. Journal of Biological Chemistry, 274, 21963-21972. http://dx.doi.org/10.1074/jbc.274.31.21963

[40] Sandmann, S., Prenzel, F., Shaw, L., Schauer, R. and Unger, T. (2002) Activity Profile of Calpains I and II in Chronically Infracted Rat Myocardium-Influence of the Calpain Inhibitor CAL 9961. British Journal of Pharmacology, 135, 1951-1958. http://dx.doi.org/10.1038/sj.bjp.0704661

[41] Sato, K., Tsuchiya, N., Sasaki, R., Shimoda, N., Satoh, S., Ogawa, O. and Kato, T. (1999) Increased Serum Levels of Vascular Endothelial Growth Factor in Patients with Renal Cell Carcinoma. Japanese Journal of Cancer Research, 90, 874-879. http://dx.doi.org/10.1111/j.1349-7006.1999.tb00829.x

[42] Glading, A., Reynolds, I.J. and Shiraha, H. (2004) Epidermal Growth Factor Activates M-Calpain (Calpain II), at Least in Part, by Extracellular Signal-Regulated Kinase-Mediated Phosphorylation. Molecular and Cellular Biology, 24, 2499-2512. http://dx.doi.org/10.1128/MCB.24.6.2499-2512.2004 